\title{
HE-ISOTOPIC INVESTIGATION OF GEOTHERMAL GASES FROM THE TABAR- LIHIR-TANGA-FENI ARC AND RABAUL, PAPUA NEW GUINEA
}

\author{
K.A. Farley, Desmond Patterson, and Brent McInnes
}

Department of Geological and Planetary Sciences, MS 170-25 Caltech, Pasadena, CA 91125

\begin{abstract}
In order to investigate the behavior of slab-derived volatiles in the subduction environment, helium isotope ratios have been measured in geothermal gases from the Tabar-Lihir-TangaFeni (TLTF) chain in the Bismarck Archipelago of Papua New Guinea. As recorded by several geochemical tracers, these volcanos carry an exceptionally large slab-derived component, and therefore may provide new insights to the old question of volatiles in subduction zones. Geothermal gases from Lihir Island have homogeneous ${ }^{3} \mathrm{He} /{ }^{4} \mathrm{He}$ ratios of $7.18 \pm 0.07$ times the atmospheric ratio $\left(R_{A}\right)$, while those from Ambitle Island (Feni Group) have lower ratios of $6.61 \pm 0.13 R_{A}$. These ${ }^{3} \mathrm{He} /{ }^{4} \mathrm{He}$ ratios are within the range defined by more-typical arc volcanos, but lie at the low end of the spectrum observed in arc volcanos erupted through purely oceanic crust. Although a small slabderived signature $\left({ }^{3} \mathrm{He} /{ }^{4} \mathrm{He}\right.$ ratio lower than depleted mantle) exists in the TLTF gases, these data demonstrate that even in volcanos with a comparatively large slab component, $\mathrm{He}$ is overwhelmingly derived from the depleted mantle wedge. This observation further confirms the relative insensitivity of $\mathrm{He}$ isotopes to the presence of slab fluids.

He isotope ratios of $6.25 \mathrm{R}_{\mathrm{A}}$ were measured in geothermal gases from the Rabaul Caldera on New Britain Island. Coincidentally, these samples were taken six months prior to the major 1994 eruption at Rabaul. In conjunction with samples taken from the same locality 8 years earlier, these data allow us to test whether increasing $\mathrm{He}$ isotope ratios associated with fresh ascending magmas precede volcanic eruptions. Although some of the 1986 samples had much lower ${ }^{3} \mathrm{He} /{ }^{4} \mathrm{He}$ ratios $\left(5 \mathrm{R}_{\mathrm{A}}\right.$ ) than observed in 1994 , one did not. We thus find no strong evidence for a systematic rise in the $\mathrm{He}$ isotope ratio of the Rabaul fluids between 1986 and 1994 . If a ${ }^{3} \mathrm{He} /{ }^{4} \mathrm{He}$ increase did precede the Rabaul eruption, then it occurred either prior to 1986 or sometime between our 1994 sampling and the eruption.
\end{abstract}

\section{INTRODUCTION}

Convergent margin processes play a critical role in the partitioning of volatiles between the Earth's interior and atmosphere by filtering elements from the subducting package, thereby restricting their return to the mantle. Elements which are tightly retained may be returned to the deep mantle along with the residual slab, while more loosely-bound volatiles may be released to the ambient mantle in a fluid or melt phase. In the latter case, the volatiles may be expelled to the Earth's surface by arc volcanism, or possibly by ejection of fluids into the trench or shallow forearc ${ }^{1}$. It is also possible that volatiles lost from the slab may be held within a subduction-modified (metasomatized, hydrated) mantle wedge. Identification of the ultimate fate of subducted volatiles has proven difficult because the composition of the downgoing material and the outward volatile flux at subduction zones are both poorly known. In addition, volatiles released by supra-subduction zone volcanos are often dominated by a component derived from the depleted upper mantle, making it difficult to uniquely identify the slab flux.

Helium isotopic measurements of arc and back-arc volcanic systems can potentially be used to address these issues because there is likely to be a large contrast between the ${ }^{3} \mathrm{He} /{ }^{4} \mathrm{He}$ ratio of the subducting and depleted mantle components. As recorded in mid-ocean ridge basalts (MORBs) the depleted mantle has a relatively uniform ${ }^{3} \mathrm{He} /{ }^{4} \mathrm{He}$ ratio of $8 \pm 1$ times the atmospheric value $^{2,3}\left(8 \mathrm{R}_{\mathrm{A}}\right)$. Subducted material is likely to have much lower ratios. Helium within the subducting package is composed of atmospheric and radiogenic components, with a possible addition of extraterrestrial (ET) helium from micrometeorite fallout ${ }^{4}$. ET helium is characterized by very 
Figure 1. Geologic setting of the TLTF Islands. Triangles indicate Quaternary volcanic centers associated with subduction at the New Britain Trench. This figure is from McInnes and Cameron ${ }^{10}$.

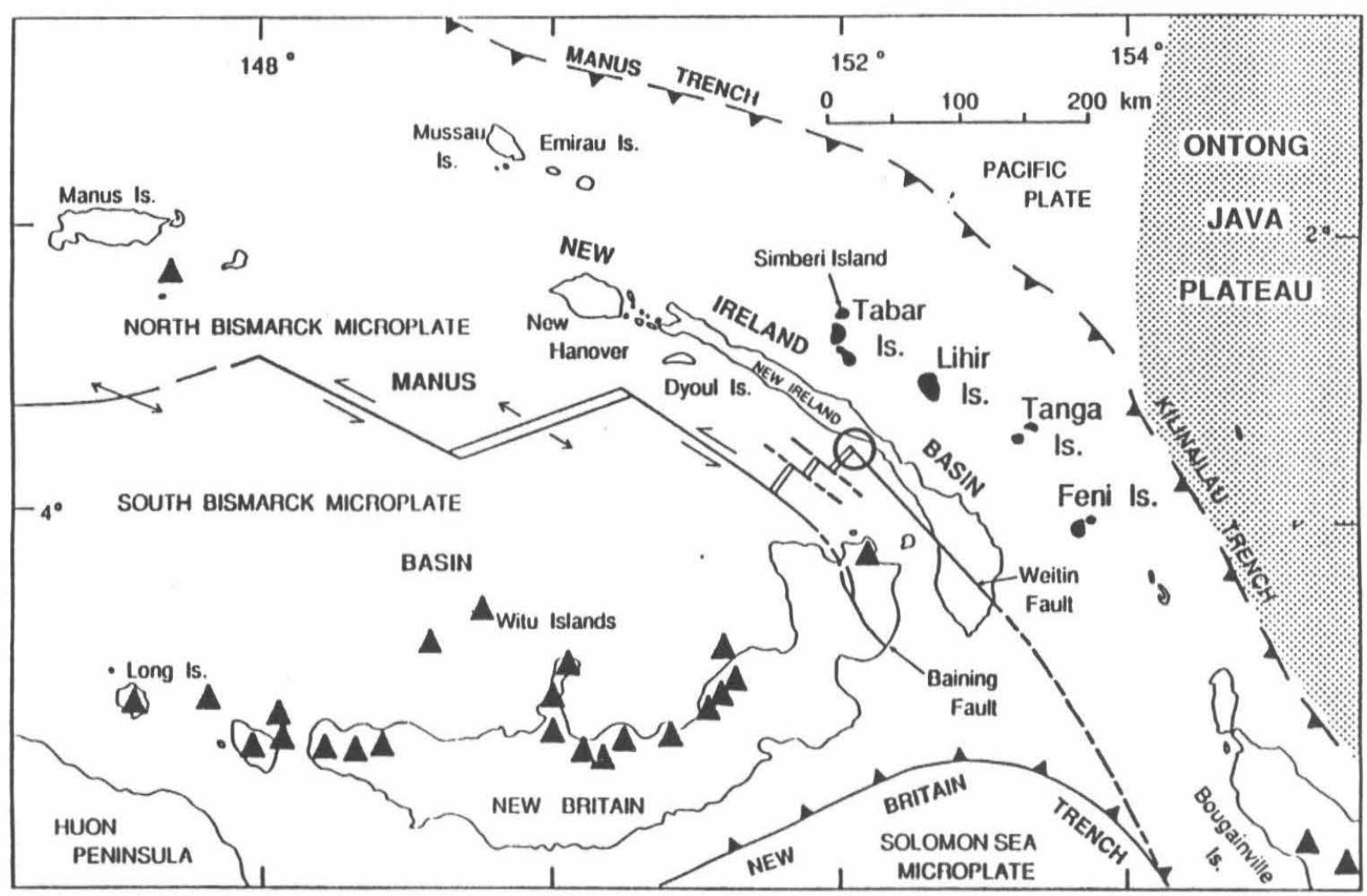


high ${ }^{3} \mathrm{He} /{ }^{4} \mathrm{He}$ ratios $\left(>100 \mathrm{R}_{\mathrm{A}}\right.$ ), but recent experimental studies indicate that it readily diffuses out of the sediments and is likely lost in the very shallowest portions of the subduction system ${ }^{5}$. Thus entrapment of atmospheric helium $\left({ }^{3} \mathrm{He} /{ }^{4} \mathrm{He}=1 \mathrm{R}_{A}\right)$ and radioactive decay of $\mathrm{U}$ and $\mathrm{Th}\left({ }^{3} \mathrm{He} /{ }^{4} \mathrm{He}<<1\right.$ $R_{A}$ ) in the sediments and altered oceanic crust probably give the downgoing package a sub-atmospheric ${ }^{3} \mathrm{He} /{ }^{4} \mathrm{He}$ ratio.

He isotope ratios in arc-related geothermal gases range from the MORB value to $<1 R_{A}$ (refs 6-9). In most cases the low values arise from addition of crustal helium to the gases, or possibly as a consequence of crustal contamination of the magmas. In general, the uncontaminated magmas themselves are thought to have almost MORB-like ${ }^{3} \mathrm{He} /{ }^{4} \mathrm{He}$ ratios ${ }^{8}$. This demonstrates that in most cases the helium budget of arc volcanos is overwhelmingly dominated by a depleted mantle component derived from the mantle wedge, effectively precluding the use of He isotopes for exploring slab devolatilization in normal arc settings.

Recent chemical, isotopic, and geophysical evidence suggests that the unusual volcanos of the Tabar-Lihir-Tanga-Feni (TLTF) arc of the Bismarck Archipelago, Papua New Guinea (Figure 1) carry an exceptionally large component derived either directly from the slab or from mantle wedge severely-metasomatized by slab fluids ${ }^{10,11}$. These volcanos potentially offer a unique opportunity to investigate the fate of subducted volatiles with helium isotopes.

A further reason for studying the TLTF volcanos is that they host significant volcanigenic gold deposits, including the world-class Ladolam Mine on Lihir Island. On both Lihir and Ambitle (Feni Group) gold deposits occur within calderas which are still highly geothermally active ${ }^{12}$. The genesis of the TLTF ore deposits may be related to the presence of oxidizing fluids derived from the slab, possibly traceable with helium.

We have also analyzed geothermal gases from the Rabaul Caldera of Eastern New Britain. These samples were collected just prior to the largest eruption at Rabaul in 50 years $^{16}$.

\section{GEOLOGIC SETTING AND SAMPLES}

The Bismarck Archipelago lies in a tectonically complex portion of the western Pacific Ocean (Figure 1). Westward subduction of the Pacific plate beneath the Indo-Australian Plate at the Manus-Kilinailu (M-K) Trench occurred until approximately $10 \mathrm{Ma}$ ago, when the buoyant OntongJava Plateau collided with the trench and precipitated subduction polarity reversal and migration. Subduction of the Indo-Australian plate now occurs along the New Britain Trench, producing numerous Quaternary volcanic centers on the island of New Britain, including Rabaul. Poorly-understood extensional processes within the New Ireland Basin, the former forearc region of the M-K Trench system, led to the emplacement of the TLTF volcanos over about the last $5 \mathrm{Ma}$. These volcanos were most likely produced by adiabatic decompression melting of mantle wedge modified by tens of millions of years of subduction at the M-K trench ${ }^{10}$. It is also possible that these volcanos carry a component derived directly from the fossil slab underlying the wedge $\mathrm{e}^{10}$.

Both Lihir and Ambitle Island in the Feni Group have active geothermal systems (Figures 2). On Lihir, activity is largely confined to high and moderate temperature hotsprings in an area of about $15 \mathrm{~km}^{2}$ contained in the breached Luise Caldera. All major thermal areas in the caldera were sampled, including submarine springs in the harbor. A single low temperature spring in the Kinami Caldera, about $8 \mathrm{~km}$ south of Luise, was also sampled. Hotsprings on Ambitle occur predominantly within the central caldera structure, and are probably being driven by a quartz trachyte body emplaced approximately 2300 years ago ${ }^{17}$. Additional minor activity on Ambitle occurs on the outer flanks of the caldera. Sample locations are further detailed in Table 1.

The Rabaul Harbor samples were collected from two shallow submarine springs between the airport and the base of Tavurvur Volcano ("Bubbly Beach", Figure 2). These gases were collected simply to test the field gear, so no effort was made to sample Rabaul thoroughly. The composition of active gases from this general locality have been described by other workers ${ }^{16}$.

Samples were collected in pinch-seal copper tubes and were analyzed for ${ }^{3} \mathrm{He} /{ }^{4} \mathrm{He}$ and $\mathrm{He}$ and $\mathrm{Ne}$ abundances at Caltech using techniques which will be fully documented elsewhere. Estimat- 


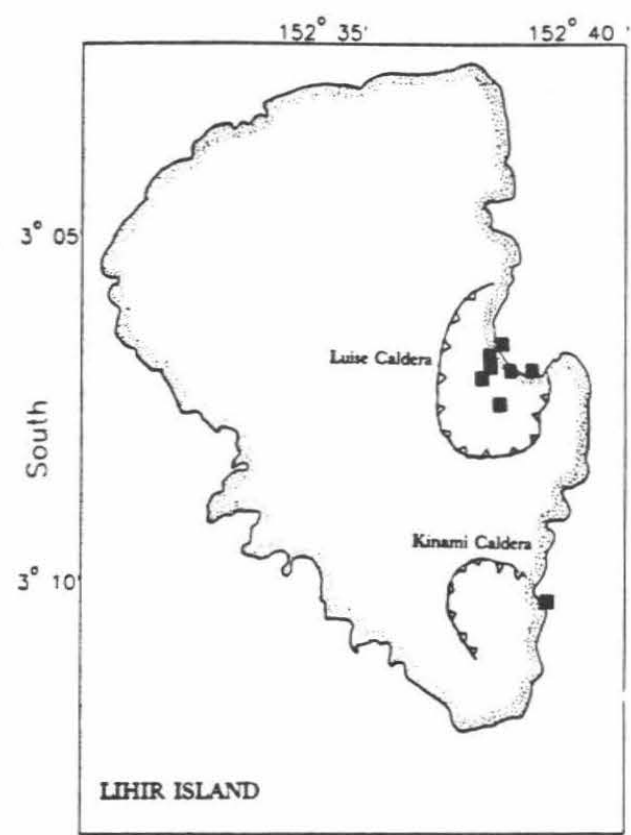

Eost

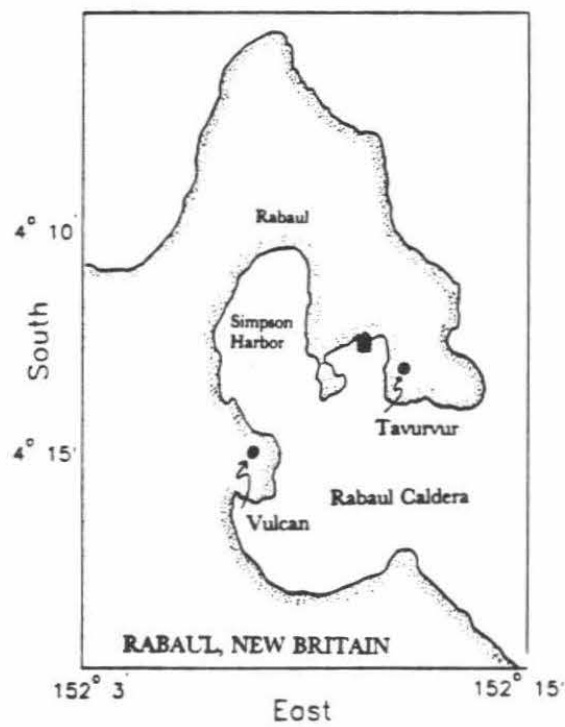

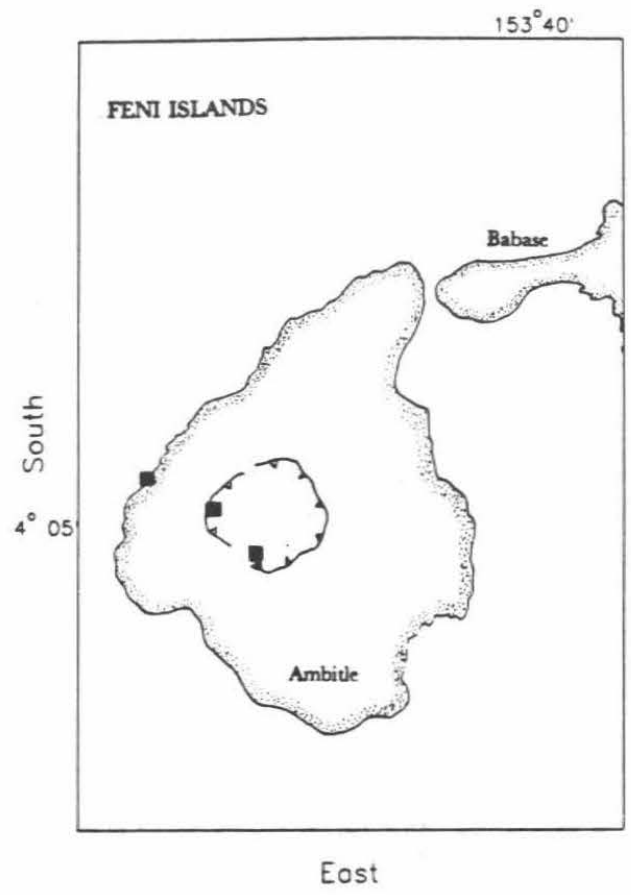

Figure 2. Locations of geothermal samples (filled boxes) from a) Lihir, b) Ambitle, and c) Rabaul. In c) the loci of the 1994 Rabaul eruption at Tavurvur and Vulcan vents are shown. 
ed uncertainties on the $\mathrm{He} / \mathrm{Ne}$ ratio and $\mathrm{He}$ abundance are about $5 \%$, while the uncertainty on the $\mathrm{He}$ isotopic ratio is $\sim 1 \%$.

\section{RESULTS}

The Table and Figure 3 present the results of these analyses. All but three samples yielded high $\mathrm{He} / \mathrm{Ne}$ ratios, ranging from 16 to 1300 times higher than the atmospheric ratio. Such high ratios imply very little contamination by atmospheric gases and adjustments to the ${ }^{3} \mathrm{He} /{ }^{4} \mathrm{He}$ ratio for this effect are very minor. The three samples with $\mathrm{He} / \mathrm{Ne}$ ratios $<10$ may have suffered much larger degrees of atmospheric addition, for which no reliable correction can be made. These samples are essentially ignored in the following discussion. For the sake of consistency with previously published work, all tabulated ${ }^{3} \mathrm{He} /{ }^{4} \mathrm{He}$ data have been corrected for air addition by assuming contamination with air saturated water ${ }^{6}$.

Excluding one locality, all gases in Luise Caldera have ${ }^{3} \mathrm{He} /{ }^{4} \mathrm{He}$ ratios which are identical within anaiytical uncertainty, at $7.18 \pm 0.07 \mathrm{R}_{\mathrm{A}}$. The exception is sample $94-\mathrm{LSUB}-3$, with a ${ }^{3} \mathrm{He} /{ }^{4} \mathrm{He}$ ratio of $6.8 \mathrm{R}_{\mathrm{A}}$. The single sample from $\mathrm{Kinami}$ is isotopically indistinguishable from the Luise fluids, and is notable for its factor of 100 enrichment in He. The Ambitle samples have distinctly lower ${ }^{3} \mathrm{He} /{ }^{4} \mathrm{He}$ ratios than those from Lihir, between 6.5 and $6.75 \mathrm{R}_{\mathrm{A}}$. Like Lihir, the samples are essentially within error of each other, averaging $6.61 \pm 0.13 \mathrm{R}_{\mathrm{A}}$. The Rabaul sample yielded a ${ }^{3} \mathrm{He} /{ }^{4} \mathrm{He}$ ratio of $6.27 \mathrm{R}_{\mathrm{A}}$, substantially lower than both Ambitle and Lihir.

\section{DISCUSSION}

\section{Lihir and Ambitle}

The helium isotopic homogeneity of the Luise samples implicates a single source for the helium in all sampled thermal areas within the caldera. It further suggests that addition of crustal helium (which would be variable, depending on the history of each sampled fluid) is probably insignificant. The ${ }^{3} \mathrm{He} /{ }^{4} \mathrm{He}$ ratio of the magmatic body driving the Luise Caldera circulation is therefore close to $7.2 \mathrm{R}_{\mathrm{A}}$. The sole outlier from this value was collected from near the edge of the caldera in very diffusely bubbling beach sands, and possibly has accumulated more-radiogenic helium from surrounding country rocks.

A magmatic body with this same He isotopic ratio apparently lies within Kinami Caldera, or alternatively, there may be subsurface flow allowing fluids from the Luise magmatic body to vent at Kinami. The high He abundance of the Kinami fluid may bear on this question. Given its high ${ }^{3} \mathrm{He} /{ }^{4} \mathrm{He}$ ratio, the $\mathrm{He}$ enrichment is not a consequence of accumulation of crustal helium, but is more likely the result of a process which preferentially concentrates helium in the gas phase. High-temperature, near-source geothermal fluids are dominated by the non-conservative gases $\mathrm{CO}_{2}$ or $\mathrm{CH}_{4}$ (ref 13). If these species are removed by chemical and/or biological reactions, the result will be enrichment of helium in the residual gas. Such an effect is more likely to occur away from the high temperature source of the fluid, and might be expected if the Kinami gas originates in the distal Luise Caldera. Further confirmation of this hypothesis requires analysis of the bulk composition of the geothermal gases.

As at Lihir, the homogeneity of ${ }^{3} \mathrm{He} /{ }^{4} \mathrm{He}$ ratios on Ambitle suggests a single magmatic source, with a ratio of about $6.6 \mathrm{R}_{\mathrm{A}}$.

The helium isotopic ratio of these magmatic systems is well-within the range observed in arc volcanos worldwide (Figure 3), suggesting that helium may not record an unusually large slab component in the TLTF lavas. However, the worldwide arc range in Figure 3 includes samples erupted through crust of a variety of ages and compositions, from young oceanic to old continental. When arc volcanos erupting through purely oceanic crust are considered separately, the ${ }^{3} \mathrm{He} /{ }^{4} \mathrm{He}$ ratios cluster near the high end of the range $\left(>7 \mathrm{R}_{A}\right)$. For example, ${ }^{3} \mathrm{He} /{ }^{4} \mathrm{He}$ ratios in the Marianas and Izu Bonin arcs range from 7.22 to $8.10 \mathrm{R}_{\mathrm{A}}$ (refs 6,9). The same observation can be made com- 


\begin{tabular}{|c|c|c|c|c|c|c|}
\hline $\begin{array}{l}\text { Sample } \\
\text { Number }\end{array}$ & Location & $\begin{array}{c}\mathrm{T} \\
\left({ }^{\circ} \mathrm{C}\right) \\
\end{array}$ & $\begin{array}{c}{ }^{3} \mathrm{He} /{ }^{4} \mathrm{He} \\
\left(\mathbf{R}_{\mathrm{A}}\right)\end{array}$ & $\frac{(\mathrm{He} / \mathrm{Ne})}{(\mathrm{He} / \mathrm{Ne})_{\mathrm{A}}}$ & $\begin{array}{c}\mathrm{He} \\
(\mathrm{ppm})\end{array}$ & $\begin{array}{c}\left({ }^{3} \mathrm{He} /{ }^{4} \mathrm{He}\right)_{\mathrm{c}} \\
\left(\mathrm{R}_{\mathrm{A}}\right)\end{array}$ \\
\hline \multicolumn{7}{|l|}{ Ambitle Island } \\
\hline 94-AMB-1 & $\begin{array}{l}\text { Kabang Prospect- creek-bed acid } \\
\text { hotspring }\end{array}$ & 48 & 6.22 & 16 & 3.1 & 6.50 \\
\hline 94-AMB-2B & $"$ & $n$ & 6.50 & 18 & 2.9 & 6.75 \\
\hline 94-AMB-3B & Caldera Saddle acid hotspring & 92 & 6.56 & 640 & 17 & 6.57 \\
\hline 94-AMB-4B & Bubbling beach near Danlam & 65 & 6.48 & 8.9 & 1.4 & 7.02 \\
\hline \multicolumn{7}{|l|}{ Lihir Island - } \\
\hline \multicolumn{7}{|l|}{ Luise Caldera } \\
\hline 94-LUI-1 & Ladolam - acid hotspring & 92 & 7.23 & 830 & 10 & 7.23 \\
\hline 94-LUI-2A & $\begin{array}{l}\text { Ladolam - creek-bed bubbling } \\
\text { vent }\end{array}$ & 25 & 7.14 & 830 & 14 & 7.14 \\
\hline 94-LUI-3A & Lower Kapit - neutral hotspring & 80 & 7.08 & 180 & 5.0 & 7.11 \\
\hline 94-LUI-4 & Lower Kapit - muddy acid pool & 65 & 7.17 & 33 & 5.1 & 7.33 \\
\hline 94-LUI-5A & $\begin{array}{l}\text { Kapit Beach - acid hotspring in } \\
\text { alteration zone }\end{array}$ & 92 & 7.11 & 1300 & 4.8 & 7.11 \\
\hline 94-LUI-6 & Kapit Beach - bubbling sand & 99 & 7.10 & 1300 & 5.2 & 7.10 \\
\hline 94-LUI-7 & $\begin{array}{l}\text { Between Kapit Beach and Lower } \\
\text { Kapit, acid hotspring }\end{array}$ & 88 & 7.07 & 28 & 4.2 & 7.25 \\
\hline 94-LUI-8A & $\begin{array}{l}\text { Upper Kapit, N. slope acid } \\
\text { hotspring }\end{array}$ & 88 & 7.15 & 240 & 8.0 & 7.17 \\
\hline 94-LUI-9B & Upper Kapit, S. slope & 42 & 7.17 & 200 & 7.4 & 7.19 \\
\hline 94-LUI-10A & $\begin{array}{l}100 \mathrm{~m} \text { NW. of Lihir Mining } \\
\text { Camp - bubbling beach sand }\end{array}$ & 95 & 6.42 & 0.23 & 0.18 & - \\
\hline 94-LUI-10B & -duplicate- & $"$ & 6.64 & 1.46 & 0.33 & - \\
\hline 94-LSUB-1B & $\begin{array}{l}\text { Luise Harbor, offshore of Kapit } \\
\text { Village, } 10 \mathrm{~m} \text { depth submarine }\end{array}$ & & 7.17 & 260 & 5.1 & 7.19 \\
\hline 94-LSUB-3A & $\begin{array}{l}\text { Lihir Mining Camp Boat } \\
\text { Launch, bubbling sand }\end{array}$ & 69 & 6.73 & 48 & 5.9 & 6.82 \\
\hline 94-LSUB-3B & -duplicate- & $"$ & 6.68 & 52 & 5.2 & 6.77 \\
\hline \multicolumn{7}{|l|}{ Kinami Caldera } \\
\hline 94-KIN-1 & $\begin{array}{l}\text { Bubbling vent in reef offshore of } \\
\text { Kinami Village, } 1 \mathrm{~m} \text { depth }\end{array}$ & 41 & 7.04 & 140 & 750 & 7.08 \\
\hline \multicolumn{7}{|l|}{ Rabaul Harbor } \\
\hline 94-RAB-1 & $\begin{array}{l}\text { "Bubbly Beach", shallow } \\
\text { submarine vent in lava, near } \\
\text { Tavurvur volcano }\end{array}$ & 78 & 6.26 & 4.9 & 0.18 & 7.29 \\
\hline 94-RAB-2 & $\begin{array}{l}\text { "Bubbly Beach", shallow } \\
\text { submarine vent in sand }\end{array}$ & 52 & 6.24 & 130 & 0.50 & 6.27 \\
\hline
\end{tabular}




\section{Purely Oceanic Arcs}

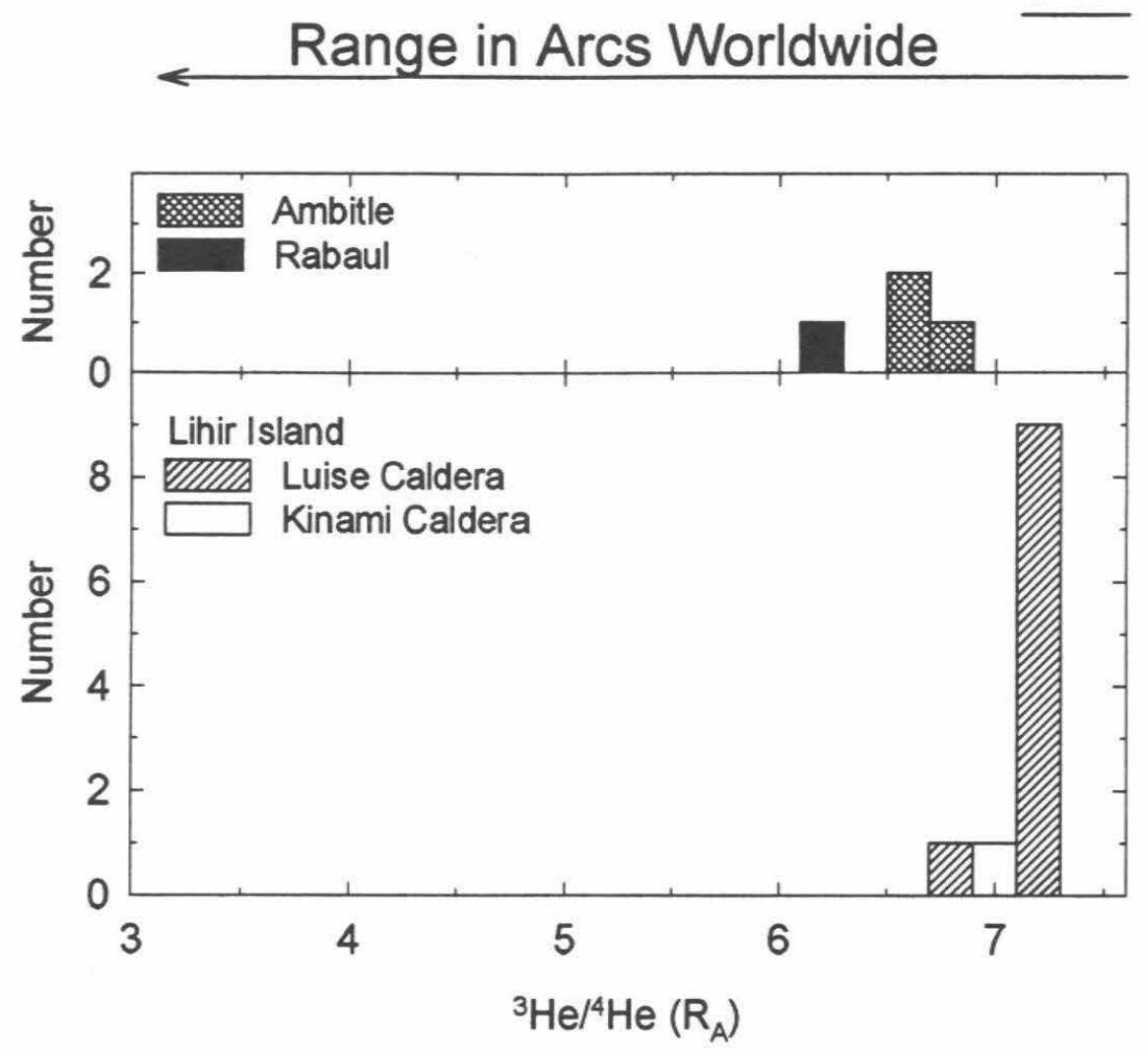

Figure 3. Corrected helium isotopic ratios in the TLTF and Rabaul gases. Shown for comparison are the range of $3 / 4$ ratios in arc volcanos worldwide, and in arc volcanos erupting purely through oceanic crust. Data for other arcs are from refs $6-9,13$ and $H$. Craig, unpublished. 


\section{He-Isotopic Investigation of Geothermal Gases}

pletely within the Bismarck Archipelago (Figure 1). ${ }^{3} \mathrm{He} /{ }^{4} \mathrm{He}$ ratios within the purely oceanic portions of the New Britain arc have ${ }^{3} \mathrm{He} / 4 \mathrm{He}$ ratios $>8 \mathrm{R}_{\mathrm{A}}$, whereas those underlain by the older arc crust of New Britain Island (including Rabaul) have ${ }^{3} \mathrm{He} /{ }^{4} \mathrm{He}$ ratios ranging downward from $6.2 \mathrm{R}_{\mathrm{A}}$ (H. Craig, personal communication, and our Rabaul data). On the bases of similar arguments, it has been suggested ${ }^{13,18,6,8}$ that most parental arc magmas are characterized by MORB-like ${ }^{3} \mathrm{He} /{ }^{4} \mathrm{He}$ ratios $\left(8 \mathrm{R}_{\mathrm{A}}\right)$, and that the lower ${ }^{3} \mathrm{He} /{ }^{4} \mathrm{He}$ ratios commonly observed may simply be the product of contamination by helium within the uppermost crust.

Because the TLTF samples are erupting through oceanic crust, and for the reasons described above, we believe our ${ }^{3} \mathrm{He} /{ }^{4} \mathrm{He}$ ratios represent uncontaminated magmatic values. This supposition is supported by preliminary helium analyses of phenocrysts from primitive basalts from these islands, which match the geothermal gases extremely well ${ }^{14}$. If it is true that uncontaminated arc magmas are characterized by MORB-like He, then the TLTF arc may indeed have a small slab-derived helium component that is more strongly manifest at Ambitle than at Lihir. Although speculative, the along-strike variation within the TLTF chain may arise because the sub-Lihir mantle has been convectively flushed by rising MORB-like magmas associated with the actively-spreading Manus Bark-arc basin, to the southwest (Figure 1). A tectonic association between Lihir and the Manus Basin is supported by structural features on and near Lihir (including several recently discovered seamounts) which lie on an extension of the Manus spreading center through New Ireland ${ }^{15}$.

In any case, as in most arc settings, $\mathrm{He}$ in the volcanos of the TLTF chain is dominantly derived from the depleted mantle wedge. Thus even in a locality where a slab component is thought to be unusually large, He does not provide a particularly good tracer for slab volatiles. This likely reflects the fact that the downgoing package is very poor in helium relative to the wedge.

\section{Rabaul}

It has been suggested that the ${ }^{3} \mathrm{He} /{ }^{4} \mathrm{He}$ ratio of volcanic gases may rise when fresh magma, uncontaminated by crustal helium, enters an existing magma chamber ${ }^{18}$. As a consequence, rising ${ }^{3} \mathrm{He} / 4 \mathrm{He}$ ratios may signal an increased likelihood of impending volcanic eruption. In conjunction with previous data, our Rabaul samples allow us to test this prediction. Our samples from Rabaul were taken on April 16,1994, shortly prior to a major eruption which commenced on September 21 . This eruption was focused through several intracaldera vents, including one (Tavurvur) within a few hundred meters of the sampled spring (Figure 2c). This same general area was sampled by H. Craig in March of 1986.

We collected two gas samples which yielded identical raw ${ }^{3} \mathrm{He} /{ }^{4} \mathrm{He}$ ratios of $6.25 \mathrm{R}_{\mathrm{A}}$. While one of these had a low $\mathrm{He} / \mathrm{Ne}$ ratio ( 5 times atmospheric), the agreement between the two samples leads us to suspect that there has been no significant addition of atmospheric helium to either sample. In 1986, one sample was collected from a vent on the summit of Tavurvur, while two samples were taken in the immediate vicinity ( \pm 50 meters) of our sampling location. The Tavurvur sample yielded a ${ }^{3} \mathrm{He} /{ }^{4} \mathrm{He}$ ratio of $5.1 \mathrm{R}_{\mathrm{A}}$. Of the samples taken very close to ours, one yielded a ${ }^{3} \mathrm{He} /{ }^{4} \mathrm{He}$ ratio of $4.55 \mathrm{R}_{\mathrm{A}}$, while the other had a low $\mathrm{He} / \mathrm{Ne}$ ratio (3 times atmospheric) but a much higher raw ${ }^{3} \mathrm{He} /{ }^{4} \mathrm{He}$ ratio of $6.2 \mathrm{R}_{\mathrm{A}}$ ( $\mathrm{H}$. Craig, personal communication). The corrected ${ }^{3} \mathrm{He} /{ }^{4} \mathrm{He}$ ratio of the latter sample cannot be reliably calculated, but because air contamination can only lower ${ }^{3} \mathrm{He} /{ }^{4} \mathrm{He}$, the raw ratio provides a solid lower limit for this sample. We find the similarity in the raw ratios in the two 1994 samples and this 1986 sample to be striking.

Two of the 1986 samples indicate an increase in the ${ }^{3} \mathrm{He} /{ }^{4} \mathrm{He}$ ratio between 1986 and 1994 , but the third does not. While not conclusive owing to the limited spatial and temporal resolution of the sampling, these observations do not provide strong evidence for a systematic increase in the ${ }^{3} \mathrm{He} / 4 \mathrm{He}$ ratio of Rabaul geothermal fluids in the 8 years preceding the September 1994 eruption. This observation suggests either 1) magmas injected into the Rabaul magma chamber did not have an isotopic contrast with the magmas/fluids already present; or 2) injection occurred either prior to 1986 , or between the 1994 sampling and the eruption. The possibility of emplacement prior 
to 1986 is given some support by the fact that an intense seismic crisis (consistent with rising magma) was observed within Rabaul Caldera between 1983 and 1985 (ref 19). A post-eruption sampling of Rabaul fluids would be useful to further constrain this issue.

\section{CONCLUSIONS}

Although the volcanos of the TLTF arc are believed to carry an unusually large slab signature, geothermal fluids from Lihir and Ambitle Islands have ${ }^{3} \mathrm{He} /{ }^{4} \mathrm{He}$ ratios only slightly lower than mid-ocean ridge basalts and fluids sampled from other purely oceanic arc volcanos. As at most arcs, $\mathrm{He}$ in the TLTF fluids is derived overwhelmingly from the mantle wedge and not from the slab, and therefore is not a useful tracer of slab volatiles. On both islands the geothermal gases are being driven by very late-stage magmas which are compositionally different from those responsible for stratovolcano construction. Thus analyses of phenocryst-borne helium are necessary to determine if this conclusion applies to all phases of volcanic activity on these islands.

Geothermal gases sampled from the Rabaul Caldera in 1986 and 1994 show no systematic change in $\mathrm{He}$ isotopic ratio preceding the large September 1994 eruption.

\section{ACKNOWLEDGEMENTS}

We wish to thank the Lihir Management Company and Father Tony Gendusa for providing invaluable assistance in collecting these samples. We also thank $\mathrm{H}$. Craig for allowing us to cite his unpublished data from the Bismarck Archipelago. H. Hiyagon provided a helpful review. This work was supported by NSF OCE-9402159 to KAF.

\section{REFERENCES}

1. Fryer, P., Pacific Science 44, 95-114 (1990).

2. Craig, H. \& Lupton, J. E., Earth Planet. Sci. Lett.31, 369-385 (1976).

3. Kurz, M. D. et al., Earth Planet. Sci. Lett. 58, 1-14 (1982).

4. Ozima, M. et al., Nature 311, 449-451 (1984).

5. Hiyagon, H., Science 263, 1257-1259 (1994).

6. Poreda, R. \& Craig, H., Nature 338, 473-478 (1989).

7. Hilton, D. R. \& Craig, H., Nature 342, 906-908 (1989).

8. Gasparon, M., Hilton, D. R. \& Varne, R., Earth Planet. Sci. Lett. 126, 15-22 (1994).

9. Tsunogai, U. et al., Earth Planet. Sci. Lett. 126, 289-301 (1994).

10. McInnes, B. I. \& Cameron, E. M., Earth Planet. Sci. Lett. 122, 125-141 (1994).

11. Kennedy, A. K., Hart, S. R. \& Frey, F. A., J. Geophys. Res. 25, 6929-6942 (1990).

12. Wallace, D. A. et al., Australian B. of Min. Res. Geology and Geophys. Report 243 (1983). 
90 He-Isotopic Investigation of Geothermal Gases

13. Giggenbach, W. F., Sano, Y. \& Wakita, H., Geochim. Cosmochim. Acta 57, 3427-3455 (1993).

14. Patterson, D. B., Farley, K. A. \& McInnes, B., EOS Trans. Am. Geophys. Union 75, 740 (1994).

15. Herzig, P. et al., EOS Trans. Am. Geophys. Union 75, 513-515 (1994).

16. Obzhirov, A.I., Geomarine Lett. 12, 54-59 (1992).

17. Licence, P.S., Terrill, J.E. \& Fergusson, L.J. Pacific Rim Congress 87, 273-278 (1987).

18. Sano, Y., \& Wakita, H., J. Geophys. Res. 20, 8729-8741 (1985).

19. Mori, J., \& Mckee, C. Science 235, 193-194 (1987). 